\title{
THE LGBTQ ISSUE AS A SUPPLEMENTARY TOOL FOR POLARIZATION IN POST-SOVIET COUNTRIES - THE CASE OF GEORGIA
}

\author{
George GEGUCHADZE, MA, Ph.D., \\ Political Science Researcher, Caucasus International University, Tbilisi, Georgia. \\ E-mail: gogigeguchadze@yahoo.com \\ Maia URUSHADZE, Ph.D., \\ Journalist, Media expert, Political Science Ph.D., Caucasus International University, \\ Tbilisi, Georgia. E-mail: maya.urushadze@gmail.com
}

\begin{abstract}
At present, when pandemic enters a new phase, the geopolitical confrontation between the adherents of unipolar and multipolar international security systems takes its new impetus. Besides the pandemic restrictions used widely as a tool of political pressure, the $L G B T Q$ issue recently gained new importance. LGBTQ activists that announced pride in the Georgian capital have not taken to the main avenue of Tbilisi out of fears of violence. Instead, anti-LGBTQ groups' representatives used physical violence against media representatives because of their perceived pro-LGBTQ/Western stance. As it is known LGBTQ issue has become quite divisive not only in Georgia but in EU member countries. The present paper discusses developments in Georgia and the post-Soviet area as an example of a small proxy state of the former Soviet Union as an arena of struggle between the West and East on values shared by the most Western democracies.
\end{abstract}

Keywords: LGBTQ; politics; violence; Georgia; propaganda.

\section{Introduction}

At present, the LGBTQ issue has been overshadowed by other issues in the political agenda of Georgia. These issues besides pandemic, include local elections, economic challenges and polarization of the society in general. Although, the events of July of this year related to LGBTQ issues played a substantial role in shaping polarized society prior to the severe challenges that took place later mentioned above. Society polarization has become so problematic today that the international society continuously stresses the importance of this issue to the government as well as all the political actors in the country. It seems to be a paradox that in Georgia, even those political actors that actually contribute to polarization in their political struggle, highlight the importance of overcoming it in their rhetoric. In these conditions it is clear that every issue which contains a divisive impulse might serve as a powerful tool to impede further development of the country.

At the same time the LGBTQ issue acquired a global geopolitical dimension and has become probably the most successful target for anti-Western sentiments in the post-Soviet area. Georgia is also facing substantial polarization of society regarding this issue. The polarization that resulted in confrontation between and within different institutions (media, church and the government) inside the country has become especially visible during July 5-6 events of this year.

So, the purpose of this article is to demonstrate why the LGBTQ issue has become such an effective supplementary tool for deepening the polarization within Georgian society. In this 
regard, case study of the existing history of the LGBTQ issue in Georgia, the recent events held on July 5, 6 was used. Comprehensive analysis was made considering mentality, ethnopolitical, territorial, economic, military and historical issues that shall be taken into consideration. The trends reflecting attitudes towards the LGBTQ community in the nearest past and present have been analysed using the content analysis of the statements of the politicians, and the media publications. Also, the surveys made via The Caucasus Research Resource Centers (CRRC) ${ }^{1}$ related data analysis tool the "Caucasus barometer" ${ }^{2}$ were analyzed.

The article consists of brief description of developments of July 5-6 events regarding violence related to the LGBTQ issue followed by description of human rights mentality characteristic for the former Soviet space. Next issue discussed in the article concerns the problems (ethnopolitical, territorial, military and economic) that are used by destructive propaganda to deepen the social polarization in the country. Historical analysis was used to show the mentality problems inherited from the Soviet past. Also, we consider that traditional values, Western values are concepts that are used as opposing ones to aggravate polarization in the country.

Under traditional values we mean the set of values important for Georgian society that are close to the following definition: "Ideas that are considered to be of great importance in life and that are, or have been, transmitted from one generation to succeeding generations." As for the Western values, we mainly mean the declared EU values (The European Commission n.d.) which are common to the EU countries (inclusion, tolerance, justice, solidarity and nondiscrimination). As to the concept of propaganda, we use the following definition: "propaganda is the interpretation, favorable for the propagandist, of a fact, a point of view, an argument, an idea or a value, including the purposefully distorted information, which shapes the society's opinion and can be used for misleading the society" (Urushadze 2019).

\section{2021 July $5^{\text {th }}$ and $6^{\text {th }}$ Events}

During 2021 July 5th and 6th events in Georgia conservative forces managed to demonstrate their strength in the streets of Tbilisi, so they showed already existing trends in a new light. According to the Director of the Heinrich Böll Foundation Tbilisi Office Dr. Sonja Schiffers: "The country has never seen such an escalation of hatred aimed at democratic civil society. Members of civil society and particularly of the media and the LGBTIQ+ community experienced traumatic violence that will haunt them for years to come" (Schiffers 2021).

Actually, the LGBTQ issue is viewed by the part of society sharing conservative views in Georgia as the most controversial and weakest point in the whole set of the Western values. It is mostly perceived as agressive propaganda of LGBTQ rather than protection of the rights of humans with different sexual orientations. This issue causes a lot of controversy even inside the EU - its member country Hungary recently enacted legislation against LGBTQ propaganda, also, neighbouring countries Turkey and Russia are in the vanguard of anti-LGBTQ movement that is perceived or portrayed as a movement against Western values in general.

As San-Francisco University scholar, Tsygankov mentions "Because of the West's tendency to promote its values as "universal," many nations across the world tend to dismiss them as inappropriate and reflective of the West's power ambitions". At the same time, the author notes that Russia views itself as the proponent of traditional values: "In his 2013 address

\footnotetext{
${ }^{1}$ A.N.: The Caucasus Research Resource Centers (CRRC) are a network of research, resource and training centers established in 2003 in the capital cities of Armenia, Azerbaijan and Georgia with the goal of strengthening social science research and public policy analysis in the South Caucasus. See: https://crrc.ge/en/

2 See: "Caucasus Barometer" - The Online Data Analysis tool (ODA) - https://www.caucasus barometer. org/en/about/
} 
STRATEGIES XXI International Scientific Conference

The Complex and Dynamic Nature of the Security Environment

to the Federal Assembly, Putin (2013c) further positioned Russia as a "conservative" power and the worldwide defender of traditional values" (Tsygankov 2016).

It is important to note that background of the recent developments regarding LGBTQ issue, beating of tens of media representatives by the participants of counter-demonstration in Georgia and subsequent death (whether the death was caused by the injuries inflicted is still debated by the part of the government) of one cameraman created big outcry in the media. Despite the fact that LGBTQ pride has been cancelled by the organizers, the polarization in the capital reached its peak. LGBTQ issue revealed polarization between "conservatives" and "liberals" that went far beyond LGBTQ issue.

The events in July showed deeper polarization in the country that has not been so visible before. LGBTQ issue became the last drop of water in the basket but not as a priority for the Georgian population struggling with territorial conflicts. As it is known, the unresolved conflicts in Georgia resulted in tens of thousands IDP-es and refugees who fled mainly to the Russian Federation and in recent decades waves of economic immigration to the EU countries.

\section{Human rights Issues in post-soviet Mentality}

Lack of attention of the general public towards human rights issues in Georgia, namely LGBTQ issue in particular, can be attributed to many problems and challenges that are focused by the country. It is worth mentioning that the Russian Federation, using the soft power tools, is actively involved in prioritization of values in Georgia in order to achieve its geopolitical objectives. Therefore, it can use all the challenges faced by the Georgian state. Especially considering that there are a lot of issues that overshadow the LGBTQ issue even without artificial emphasis.

Human rights protection movement that includes LGBTQ community rights acquired substantial publicity in recent years. Since the late 80-es so-called non-traditional sexual orientation has not been anymore considered as a deviation from a norm, and the practices of forceful treatment have been left in the past. But, in fact, more efforts are needed in order to widely share this view in post-soviet societies, in our case - Georgian public.

LGBTQ issue was being focused primarily in the West whereas elsewhere (in the Newly Independent States of the former Soviet Union (FSU) for example in Georgia) human rights of refugees and/or internally displaced persons (IDP-es) due to protracted conflicts attracted more attention on the part of the society.

Some of the human rights, for example women rights have not been accepted in certain parts of the world. Historically, women played quite a substantial role in Georgian society. Despite these traditions, even in this regard the domestic violence rate is quite significant and increases. In 2013 domestic violence police protection orders numbered 229 whereas their number in 2019 reached around 10266. Please see the relevant figures from the State Statistic Department of Georgia . This growth can be probably explained by more attention and more awareness on the part of the police force, which is trained to react decisively. But the high growth of reported violence against women leaves less priority to LGBTQ community rights.

\section{Ethnopolitical and Territorial Problems}

In the case of Georgia, existing security challenges due to inability to solve ethnopolitical conflicts and Euro-Atlantic aspirations have to be taken into consideration as well. Failure to solve the problem of re-integration of its breakaway regions bordering with Russian Federation due to the overwhelming superiority of force on the part of the latter, subsequent borderization process at the former administrative borders of the now occupied 
territories of the former autonomous Republic of Abkhazia and South Ossetia autonomous region, put Georgia in an extremely vulnerable situation from the security point of view. It resulted in deterioration of the position of Georgia related to its aspirations to the Euro-Atlantic structures. Militarily, the Russian militaries are stationed very close to the Georgian capital that creates a very vulnerable situation for the overall security of the country. As researchers note "As a result, from a military point of view, the separatist enclaves are safe from a conventional attack, while Russia, if needed, is able to split Georgia in two in several hours, by cutting the transport infrastructure (main highways and railways) linking the western and the eastern parts of the country, and to rapidly reach with ground troops the outskirts of Tbilisi" (Secrieru 2013).

Due to the transition process, the fact that the LGBTQ issue is not at the top of the agenda of the Georgian public can be attributed to the overall negative expectations within society expressed in the media and political narratives. Some of them can be formulated as follows: despite its substantial contribution to the international security operations led by NATO in Afghanistan and other parts of the world, assurances that the Russian Federation does not possess veto over NATO expansion, there was not much progress seen in this direction at least in the nearest future. At the same time, continued borderization at the former administrative border that is called the line of occupation by Georgia and state border of the South Ossetia and Republic of Abkhazia and Russian Federation that recognized their independence in 2008, makes integration of Georgia into the Euro-Atlantic structures next to impossible in the eyes of the substantial part of the public. These negative expectations are artificially enhanced by interested external actors even further. It is understandable that in these circumstances, LGBTQ issue is being overlooked especially by the general public.

\section{Economic problems}

Economic problems also add up to security challenges outlined above. Impoverishment of the population, the biggest drop in the cumulative output of production among all former Soviet Republics (at least 68\% in 1994) according to the Report of the Vienna Institute for International Economic Studies (Iradian 2007) was experienced by Georgia in the early 1990es, after the collapse of the Soviet Union. High GDP growth beginning from 2004 and onwards was impeded by a ban on Georgian exports by the Russian Federation, also followed by the armed confrontation with Russia over separatist regions. was exacerbated by the global economic crisis in 2008. Inability to recover growth combined with 2008 war consequences resulted in current low rates of economic growth, which was affected by the current pandemic especially in the sphere of tourism and related sectors. In this regard, it must be mentioned that Russian tourists contributed substantially to the tourism industry that had increased dependence of the industry on that country, which in turn was a negative indicator for economic independence and Euro-Atlantic integration.

As to the economic cooperation of Georgia with EU vis-à-vis the Russian Federation shows that the Russian market is still a better option for Georgian goods (mainly agricultural) considering higher quality requirements and competition in the EU and brand recognition of Georgian wine in the Russian Federation. This continues despite the economic ban introduced in 2006 shortly before the 2008 war in Georgia over South Ossetia and Abkhazia. According to the report of the Georgian branch of the Transparency International, there is "a high dependence of Georgian wine export on the Russian market, Russian tourists visiting Georgia and the import of Russian wheat". According to the report:"In 2013-2019, Georgian wine exports increased by USD 158 million (244\%), of which USD 110 million came from sales in Russia" (Transparency International Georgia 2020).

It must be mentioned that unlike the young generation, the old generation "..appear to be even more sceptical than their neighbours in the post-Soviet space and are asking especially 
STRATEGIES XXI International Scientific Conference

The Complex and Dynamic Nature of the Security Environment

for more public involvement in health and old age pensions [EBRD (2007), p. 48-49]. Dissatisfaction is particularly widespread among older adults, given their personal experience of the highly inclusive Soviet welfare model, characterized by top-down organised universal social security embedded in full-employment" (Baumann 2012).

Georgian agricultural products in Soviet times did not have to compete with international competitors as it is the case at present independent Georgia. As "In more industrialized countries, which were more integrated in the European markets to begin with, the transformation may have provoked less resistance. In more rural societies, whose economies were more dependent on the Soviet Union, the reforms led to a bigger shock and stronger resistance from certain societal groups" (Snegovaya 2017).

All the above-mentioned economic problems also explain why LGBTQ issue was not top priority on the public agenda.

\section{Soviet past that is still remembered}

The next issue we intend to discuss in more detail below is nostalgia towards the Soviet past. The Soviet past is being well-remembered and sometimes idealized for some seemingly obvious reasons like the existence of a social safety net, free healthcare and education (though out-of-the pocket payments were a commonplace) are considered as advantages by the substantial part of the population as compared to the present conditions.

Although it must be mentioned that ethnopolitical conflicts have already been notable before the collapse of the Soviet Union. As professor of the Sao Paulo University Angelo Segrillo mentions: " $\ldots$ the migratory movements of the USSR tended to sharpen the problem of regional imbalances in the allocation of labor. Carrère d'Encausse joined other voices in the West (e.g., Robert Conquest, Richard Pipes, Zbigniew Brzeziński) who pointed to several worrying areas of tension in the ethnic and demographic field of the USSR, even before Perestroika" (Segrillo 2020).

Focus on some of the differences in favorable light makes the past (e.g. Soviet Union) look more attractive than present, especially considering that a significant part of the population still struggles for survival being dependent on remittances from abroad. For example, subsistence farming still represents a major type of activity in the agricultural sector whereas Soviet collective farming is perceived to ensure less stratification in the sector as compared to nowadays. As Evelin Baumann (2012) writes "Since 1990, the proportion of industrial workers has been divided by four, with one active Georgian out of five being employed in industry in 1990, but only one out of twenty in 2007 [State Department for Statistics of Georgia (1999), p. 46; Ministry of Economic Development of Georgia (2009), p. 18]“" (Baumann 2012).

Going back to the main topic, it must be mentioned that issues regarding nowadays LGBTQ rights have been addressed very negatively by the penal code, which was cancelled just in 1993. As the Ph.D. scholar at the University of Alberta Nikita Sleptcov writes, "The Yeltsin administration in 1993 excluded "muzhelozhestvo" (male-to-male sexual practice) from the Code of Criminal Offence" (Sleptkov 2018). So, LGBTQ people were perceived as "criminals" not long ago by Georgian society that was a part of the Soviet Union. Therefore, despite the fact that historically, acceptance of LGBTQ community representatives was prevalent in Georgia which enabled them to participate in public activities, the abovementioned might be one of the reasons why the substantial part of the population still hardly accepts LGBTQ rights as something evident. The above-mentioned can be confirmed also by the surveys of the Caucasus Research Resource Centers (CRRC) (Caucasus Research Resource Center n.d.). For example, the survey showed that in Georgia majority of the respondents (45\%) 
think that hate speech is directed most often at the LGBT people $;^{3} 43 \%$ of respondents think that the LGBT persons most often are the target of the hate speech $;{ }^{4} 54 \%$ of the respondents named LGBT people as a group they would not want to have as neighbors; ${ }^{5}$ LGBT people is the group which is more often associated to the minority groups $(13 \%) ;{ }^{6} 42 \%$ of the respondents think that LGBT community experiences hate crime most often in Georgia, ${ }^{7}$ and the LGBT persons the most often became victims of the hate crime $(29 \%){ }^{8}$

The same negative attitude is inherited by at least some former Eastern bloc countries. According to Dovile Šukyte, Policy Analyst from the Eastern Europe Studies Centre, Lithuania writes, the Baltic states - Lithuania, Latvia, Estonia underwent significant changes after regaining independence. But at the same time, she underlines the following: "Nevertheless, they still remain more traditional and conservative than their allies in Western Europe. It is already a considerable achievement that the Baltic Pride parades have turned into support actions for the LGBT community, instead of protests against allowing the gathering. But Kremlin's propaganda portraying the EU as undermining family values and promoting same sex marriages still has its niche and has to be countered with increased awareness and tolerance" (Šukyte 2017).

Therefore, it is clear that this narrative is extensively used by the successor of the Soviet Union - Russian Federation in its anti-Western rhetoric in Georgia as well. This rhetoric has become more pronounced considering the increasing role of the Russian Federation at the international arena. At the same time according to Sabina Strimbovchi, it must be mentioned that "Another goal of Russia was not to let the western powers to come in the region, trying as well to impede foreign investments" (Strimbovschi 2015).

\section{Armed Conflicts}

According to its leadership, it managed to overcome challenges related to internal territorial conflicts and reached its geopolitical goals first close to the Southern border, Georgia and then in Ukraine. From the geopolitical point of view, the primary objective set by Russian leadership was to control its bordering countries and prevent their potential integration into NATO using ethnic divisions inside the countries. If former independent countries are not pro-Russian, small satellites, like South Ossetia and Abkhazia as well as breakaway/occupied Ukrainian regions with huge military presence keep security concerns low especially at the Southern borders especially. It is worth mentioning that Georgia provided fertile testing ground for new strategies and tactics: "In planning for conflict with Ukraine, Russia copied what worked in Georgia and adjusted what did not. Distribution of fresh Russian passports (pasportizatsiya), the supposed casus belli of defending the rights of compatriots, and accusations of malign Western intentions were repeated in both conflicts" (Giles and Monaghan 2014).

Russian Federation aggression towards Georgia in 2008 sent a clear message to the West. According to Giles and Monaghan et al: “... use of military force has to be considered a

\footnotetext{
3 See: CRRC Poll: Which group do you think hate speech is targeted at most often in Georgia? https://www.caucasusbarometer.org/en/hs2018ge/HATGRT/

4 See: CRRC Poll: Targets of hate speech - LGBT people/homosexuals https://www.caucasus barometer.org/en/hs2018ge/HSTLGB/

5 See: CRRC Poll: Wish not to have as your neighbor - LGBT people/Homosexuals https://www.caucasus barometer.org/en/hs2018ge/NEIGBRLG/

6 See: CRRC Poll: Which minority group comes to mind first? https://www.caucasus barometer.org/en/hs2018ge/MNMIND/

${ }^{7}$ See: CRRC Poll: Which group do you think experiences hate crime most often in Georgia? https://www.caucasus barometer.org/en/hs2018ge/HCRGRT/

8 See: CRRC Poll: Targets of hate crime - LGBT people/homosexuals https://www.caucasus barometer.org/en/hs2018ge/HCTLGB/
} 
STRATEGIES XXI International Scientific Conference

The Complex and Dynamic Nature of the Security Environment

useful foreign policy tool available to Russia, a concept validated by the outcome of the armed conflict in Georgia in August 2008, which, despite Western perceptions, resolved a number of key doctrinal challenges for Russia" (Giles and Monaghan 2014).

Events in Ukraine clearly demonstrated that not only a small country like Georgia populated by up to $4 \mathrm{mln}$ people lacked resources to defend itself but even at least 10 times larger country, namely Ukraine was unable to maintain its territorial integrity due to increased hybrid capabilities of the Russian Federation. Moreover, an international agreement signed in Budapest by key states that guaranteed territorial integrity of Ukraine in exchange of refusal from nuclear warheads by Ukraine turned out to be ineffective.

On a global scale, the Russian Federation has been blamed for interference in the recent US elections, elections of EU parliament, also the Russian spies scandal in Austria represent only a few examples of the perceived attempts. According to Czech intelligence agency (BIS) "Russia [is] using puppet organizations and propaganda in the Czech Republic to stoke extremism and fuel anger toward the West" (Čižik 2017). Therefore, it positions itself as a strong military and soft power that is able to use disagreements on values that exist inside the European Union, in the West and even in the individual countries including the US.

As Emilio J. Iasiello (2017) writes "Based on its successes in Crimea, Russia is outpacing its main adversary, the United States, by leveraging the information space to bolster its propaganda, messaging, and disinformation capabilities in support of geopolitical objectives" (Iasiello 2017). Therefore, Russia's strategy towards Georgia can be described as follows: "Russia prefers to couch its Georgia strategy mainly in soft power terms that contentwise are based on a number of arguments. First, accentuating cultural and religious affinity with Georgia is for Moscow a political instrument that allows for emphasizing the incompatibility of "traditional" Orthodox values with the liberal emancipatory agenda of the EU that allegedly "calls for respecting sin" and "forgets about nations and patriotism." (Makarychev and Yatsyk 2014).

Therefore, it is clear that the defamation of the so-called Western liberal values, including LGBTQ issue, is an effective tool which is widely used by the Russian Federation in the area of its nearest neighbourhood.

\section{Polarization in society as reflection the West-Russia tensions regarding values}

Contradicting interpretations of the LGBTQ issue by anti-Western propaganda and real LGBTQ community rights protection contributes significantly to the polarization of the society. Despite the fact that LGBTQ issue is one of the integral parts of human rights in general, the destructive propaganda against "Western values" propagates LGBTQ issue as a threat to "traditional values".

In order to create wrong public opinion regarding the LGBTQ issue, the conservative forces use manipulation myths. One of them identified by the fact-checking and myth debunking platform ${ }^{9}$ of the Media Development Foundation of Georgia ${ }^{10}$ concerns the myth about same-sex marriage: "Myth No. 3: In order to join the European Union, Georgia must legalize same-sex marriage" (Reiter 2019). Being chosen by interest groups as a suitable target, LGBTQ contributed significantly to the polarization inside Georgian society and even between various institutions like Georgian-Orthodox church and part of the media. Therefore, "Rising frustration among Georgia's elites and the public with the slow pace of Western integration and increasingly effective Russian propaganda raise the prospect that Tbilisi might slow or suspend efforts toward greater Euro-Atlantic integration. Tensions with Russia will remain high, and we

\footnotetext{
${ }^{9}$ See: The Myth Detector, https://www.mythdetector.ge/en

${ }^{10}$ See: The Media Development Foundation, MDF (NGO), http://www.mdfgeorgia.ge/eng/home
} 
assess that Moscow will raise the pressure on Tbilisi to abandon closer EU and NATO ties" (Gvineria 2017). Repercussions of the value tensions between the West and Russia added up to the polarization inside Georgia.

Euro-Atlantic aspiration of Georgia includes not only formal sharing of the values but its proper understanding. This is impeded by the still existing Soviet stereotypes, problems mentioned above and anti-Western propaganda on the part of the Russian Federation to portray "Western values" including rights of LGBTQ community as an insult to the Georgian national values and immediate threat to the security and identity.

This happens given the situation when Georgia has a high level of polarization for 10 years causing concern of the international community. External actors point out to the Georgian authorities the necessity to lower down the political temperature: "More broadly, tackling the polarisation in Georgian politics and media remains a priority" (EU commission 2021). For example, the Transparency International Georgia stated in the report the following: "The election campaign before the 2018 presidential elections in Georgia was taking place against the background particular tension and confrontation" (Transparency International Georgia 2018). ISFED underlines in social media monitoring report dated November 19, 2019 regarding the facebook propagandistic pages the following: "The monitoring suggests that these pages aim to incite value-based confrontation and polarization in the society, create irrational fears, influence public discourse and radicalize the society on ideological grounds" (ISFED Georgia 2019). Despite these recommendations, temperature continues to rise and LGBTQ issue does contribute substantially in this regard.

Therefore, radicalization and consolidation of the various groups and institutions around the opposite sides which are supporting or opposing the Western attitude regarding the LGBTQ issue actually happened. The issue itself has become a painful and difficult topic to address in the Georgian political scene.

It takes place in conditions when Georgia has a high level of polarization for several years causing concern of the international community. External actors still point out to the Georgian authorities the necessity to lower down the policial temperature. Polarization and aggressive discourse is underlined in OSCE interim report dated September 17, 2021: "Several ODIHR EOM interlocutors describe the political landscape as highly polarized, and the discourse as aggressive, with frequent accusations of disinformation being spread" (Organization for Security and Co-operation in Europe 2021). The same topic was addressed by the Chair of the Delegation of the European Parliament for relations with the South Caucasus, MEP Marina Kaljurand regarding the polarization in Georgia: "I would like to urge political parties to put national interests above party interests, to bring peace and stability back to the country and to continue with topics that really do affect people on daily basis (Kaljurand 2021). Despite these recommendations, the polarization temperature continues to rise and LGBTQ issue does contribute substantially in this regard.

\section{Conclusion}

Considering all the above-mentioned, the propagandistic attacks targeting the Western values can be considered as a strategy for polarization of the society, and LGBTQ issue as its implementaion tool.

It would be mentioned that LGBTQ issue gains more importance and can be considered more closely as a potential divisive point not only between Russia and the West but also between Georgia and the West. Unlike Hungary and some other countries, this issue may become an additional divisive value that may further hinder Euro-Atlantic aspirations that have already been seen by some Georgians with scepticism. 
STRATEGIES XXI International Scientific Conference

The Complex and Dynamic Nature of the Security Environment

Considering the above-mentioned fact that the public consensus regarding LGBTQ issue in Georgia has not been reached, attempts to advocate LGBTQ rights causes strong opposition on the part of the conservative part of the society. In the given context, this struggle that takes place in Georgian society results in such an extent of radicalization that the state becomes vulnerable in terms of its security.

Provided the above-mentioned, the options of the government are limited and response to even cases of grave violations of human rights regarding LGBTQ community rights are being labelled as politically motivated. This in turn, impedes development of the country, raising awareness of the society and its consolidation based on human rights values. The government that attempts to get political dividends especially considering the local elections makes no effort to raise awareness on LGBTQ issue.

Since anti-Western propaganda portrayed LGBTQ community as a "fifth column" aimed at subduing "main" or "traditional" values, this community shall be supported by reminding what the basic human rights values are. Unfortunately, it will be reasonable to raise awareness regarding human rights not by pride parades but by educating on human rights in general including rights of LGBTQ community and inadmissibility of violence.

\section{BIBLIOGRAPHY:}

BAUMANN, Eveline. 2012. "Post-Soviet Georgia - It's a long, long way to "Modern" Social protection." Economies et Societes, Serie. URL: https://horizon.documentation.ird.fr/exldoc/pleins_textes/divers12-07/010056159.pdf

Caucasus Research Resource Center. n.d. URL: https://crrc.ge/en/

ČIŽIK, Tomáš. 2017. "RUSSIAN INFORMATION WARFARE IN CENTRAL EUROPE." In Information Warfare - New Security Challenge for Europe, CENAA. URL: https://www.researchgate.net/publication/322695565_Information_Warfare_-

_New_Security_Challenge_for_Europe

EU commission. 2021. "Georgia: EU report highlights the need for political compromise to continue the reform momentum." URL: https://ec.europa.eu/commission/ presscorner/detail/en/ip_21_425

GILES, Keir, MONAGHAN, Andrew. 2014. "Russian Military Transformation - Goal In Sight?", Strategic Studies Institute, US Army War College. URL: http://www.jstor.org/stable/resrep11669

GVINERIA, Shota. 2017. "Information Warfare as Russia's Hybrid Warfare Tool." In Information Warfare - New Security Challenge for Europe, edited by Tomáš Čižik, CENAA. URL: https://www.researchgate.net/publication/322695565_Information_ Warfare_-_New_Security_Challenge_for_Europe

IASIELLO, J. Emilio. 2017. "Russia's Improved Information Operations: From Georgia to Crimea." The US Army War College Press 47 (2). URL: https://press.armywarcollege.edu/parameters/vol47/iss2/7/

IRADIAN, Garbis. 2007. Rapid Growth in the CIS: Is It Sustainable? Analytical, Vienna: The Vienna Institute for International Economic Studies. URL: https://wiiw.ac.at/rapidgrowth-in-the-cis-is-it-sustainable-dlp-427.pdf

ISFED Georgia. 2019. Propagandistic Facebook Pages Aim To Provoke Irrational Fears and Polarization In The Society. Social Media Monitoring Report. URL: https://www.isfed.ge/eng/sotsialuri-mediis-monitoringi/propagandistuli-Facebookgverdebi-miznad-isakhavssazogadoebashi-iratsionaluri-shishebisa-da-polarizatsiisgaghvivebas-

KALJURAND, Marina. 2021. Speech of Marina Kaljurand Radio Liberty Georgian Branch website. URL: https://shorturl.at/dqPTZ 
MAKARYCHEV, Andrey, TARTU, Alexandra, and YATSYK, Kazan. 2014. "Russian World", (Non) Soft Power: Putin's Serpentine Policy in the South Caucasus." CAUCASUS ANALYTICAL DIGEST. URL: https://css.ethz.ch/content/dam/ethz/specialinterest/gess/cis/center-for-securities-studies/pdfs/CAD-67-68-2-6.pdf

Organization for Security and Co-operation in Europe. 2021. "Georgia, Local Elections." Interim Report. URL: https://www.osce.org/odihr/elections/georgia/498261

REITER, Anja. 2019. Most popular myths about LGBT people in Georgia. Media Development Foundation. Tbilisi, December 16. URL: https://www.mythdetector.ge/en/myth/mostpopular-myths-about-lgbt-people-georgia

SCHIFFERS, Sonja,S. 2021. "Pride and Prejudice: Georgia after the Escalation of Violence against Civil Society." ge.boell.org. July 15. Accessed July 15, 2021. URL: https://ge.boell.org/en/2021/07/15/pride-and-prejudice-georgia-after-escalationviolence-against-civil-society

SECRIERU, Stanislav. 2013. "Protracted Conflicts in the Eastern Neighborhood: between averting wars and building trust." BCT Neighbourhood Policy Paper. URL: https://www.khas.edu.tr/cms/cies/dosyalar/files/NeighbourhoodPolicyPaper(06)(5).pdf

SEGRILLO, Angelo. 2020. The Decline of the Soviet Union. 1. São Paulo: University of São Paulo. URL: http://lea.vitis.uspnet.usp.br/arquivos/angelosegrillobookthedecline ofthesovietunion.pdf

SLEPTKOV, Nikita. 2018. "LGBT World Politics - Political homophobia as a state strategy in Russia." Journal of Global Initiatives: Policy, Pedagogy, Perspective: 12 (1). URL: https://digitalcommons.kennesaw.edu/jgi/vol12/iss1/9

SNEGOVAYA, Maria. 2017. "Conservative Turn in Eastern Europe: Political Conservatism in Russia." Desenvolvimento em Debate 5 (1). URL: https://revistas.ufrj.br/index.php/ $\mathrm{dd} /$ article/view/32163

STRIMBOVSCHI, Sabina. 2015. "Azerbaijan's Balanced Foreign policy trapped in a volatile geopolitical context." EUROPOLITY 10 (1): 121-134. URL: http://europolity.eu/wpcontent/uploads/2016/07/Vol.-10.-No.-1.-2016-editat.121-134.pdf

ŠUKYTĖ, Dovilè. 2017. "Russian information Warfare in the Baltic States and Possibilities to Resist." By Information Warfare - New Security Challenge For Europe, edited by Tomáš Čižik. Bratislava: Centre for European and North Atlantic Affairs (CENAA). URL: https://www.researchgate.net/publication/322695565_Information_Warfare__New_Security_Challenge_for_Europe

The European Commission. n.d. The EU Values. URL: https://ec.europa.eu/componentlibrary/eu/about/eu-values/

Transparency International Georgia. 2020. Georgia's Economic Dependence on Russia: Trends and Threats. Tbilisi, May 04. URL: https://transparency.ge/en/blog/georgias-economicdependence-russia-trends-and-threats

Transparency International Georgia. 2018. Hate speech and polarization in the pre-election period. December 06. URL: https://transparency.ge/en/blog/hate-speech-andpolarization-pre-election-period

Tsygankov, Andrei. 2016. "Crafting the State-Civilization Vladimir Putin's Turn to Distinct Values." Problems of Post-Communism 63 (3): 146-158. URL: https://doi.org/10.1080/10758216.2015.1113884

Urushadze, Maya. 2019. "Projecting the Foreign Propaganda on the Georgian Politics." Ante Portas - Security Studies 12 (1): 53-65. URL: https://doi.org/10.33674/220194 